\title{
Using Tax Policy To Curb Speculative Short-Term Trading
}

JOSEPH E. STIGLITZ

Professor of Economics

Stanford University

This article addresses the question of the desirability of a tax on transactions in the securities industry. Many of the other major industrialized economies impose such a tax. In Japan, for instance, the tax raises $\$ 12$ billion a year (see Roll, 1989). I propose to consider the consequences of a tax at a relatively low rate, say .5 percent to 1 percent of the value of the transactions. ${ }^{1}$

Underlying my analysis are two presumptions. First, as an economist, I begin with a general suspicion against narrowly based taxes (as opposed to broadly based taxes, such as income taxes). Such taxes frequently introduce unnecessary distortions, ${ }^{2}$ and they are often inequitable, since the incidence of the tax is borne by those particular individuals who happen to like the commodity being taxed, or who happen to own shares in the industry producing the commodity being taxed. There are four circumstances under which governments frequently resort to selective taxes: (1) the commodity being taxed has a highly inelastic demand, so that the tax has little distortionary effect; (2) the commodity being taxed is a luxury good, consumed largely by the very rich, and not much weight is accordingly attached to the reduction in its consumption (perfume falls into this category); (3) the commodity being taxed is associated with certain benefits provided by the government (a benefit tax)-gasoline and airport taxes fall within this category; and (4) the commodity being taxed has some socially undesirable characteristics, such as giving rise to a negative externality. Alcohol and cigarette taxes-in spite of their regressive nature-are justified on the grounds of their inelastic demand and the negative social attributes of these commodities. Where gambling is legalized, it is almost always heavily taxed. Corrective (or Pigovian) taxes are designed to ameliorate some externality, where there is a deviation between private and social costs and benefits.

The second premise is that well-functioning capital markets play a vital role in modern capitalist economies. It is important that firms be able to raise capital and that risks be spread

This article, prepared for the Conference on Regulatory Reform of Stocks and Futures Markets, given at Columbia University, May 1989, is based in part on earlier research on the effects of capital taxes. Financial support for this research from the Office of Tax Analysis, U.S. Treasury, the National Science Foundation, the Olin Foundation, and the Hoover Institution is gratefully acknowledged. In preparing this article, I have benefited greatly from conversations with Larry Summers, and I have drawn heavily on Summers and Summers (1989) for estimates of tax revenues and other data used in this study. I have also benefited considerably from discussions of the paper during the conference at which it was presented. 
widely. I suspect that I do not need to preach the virtues of well-functioning capital markets to this reading audience.

One might have thought that from these two premises I would be led naturally to the conclusion that a tax on securities transactions is undesirable. The distortions introduced by such a tax would scem to be far worse than those associated with the selective tax on automobile tires, telephones, or the distortionary impact of the trade restrictions on textiles and shoes. For such a tax interferes with the functioning of the capital markets-an institution at the heart of American capitalism. Yet, I want to try to persuade you that such a tix may actually be beneficial.

The heart of the argument is simple: the turnover tax is likely to discourage short-term speculative trading. Keynes argued quite forcefully that such speculative trading was not only not socially productive but actually interfered with the efficient functioning of the economy. Firms were induced to pay excessive attention to short-term returns rather than long-term concerns. The arguments we put forward are slightly different and are cast in the language of modern welfare economics. But the conclusion is much the same.

The article is divided into three major sections. In the first, I argue that a tax on transactions will not interfere with the major economic functions served by the stock market - and may well enable the market to serve its essential functions more effectively. This argument is predicated on the assumption that a turnover tax does not increase-and may actually reduce-price volatility. Hence in the second section, I explain why a tax on transactions is likely to reduce price volatility. In the third, I take up a few practical problems associated with the implementation of such a tax.

In my description below, I shall focus my attention on stocks, but most of the arguments apply with equal force to other capital markets.

\section{The consequences of a turnover tax on economic efficiency}

To understand the consequences of a turnover tax on trades on the stock market, we first have to understand why individuals trade and what the economic functions are that the stock market serves.

There are, of course, a variety of reasons for trade. Individuals buy shares during phases of their life cycle when they are saving, and sell during phases of their life cycle when they are dissaving. Changes in economic circumstances may lead individuals to wish to change their portfolios, entailing selling some securities and buying others. But most of the short-term trading in the stock market is motivated by quite different considerations: individuals believe that they can beat the market, either because they are privy to insider information, or at least information that is not widely available, or because they believe that they are better able to interpret the world around them, and thus make predictions concerning the performance of various securities, than are other investors. That is, most trades are based on (the belief of) differential information.

A standard result in economics is that the market system provides incentives that ensure economic efficiency. In this view, then, the fact that private returns seem so high on Wall Street is indicative that there is an important social function being performed. A major thrust 
of theoretical research in economics during the past half-century has been understanding the conditions under which there is a close congruence between social and private returns. General results (Greenwald and Stiglitz, 1986) show that when informational problems, such as those with which we are concerned here, arise, the market is not in general (constrained Pareto ${ }^{3}$ ) efficient. The reason for this may be seen intuitively as follows. ${ }^{4}$ Assume that as a result of some new information, there will be a large revaluation of some security, say from $\$ 10$ to $\$ 50$. Assume that that information will be announced tomorrow in the newspaper. What is the private versus social return to an individual obtaining the information today? Assume the firm will take no action on the basis of the informationcertainly not as a result of knowing the information a day earlier. There is really no social return to the information; production, in every state of nature, in every contingency, is precisely what it would have been had the information not been available. But an individual can buy the stock today, at $\$ 10$, and make a $\$ 40$ capital gain. He or she can obtain a four-fold return on his or her investment. Of course, some one else would have obtained the return had he or she not purchased it. The information has only affected who gets to get the return. It does not affect the magnitude of the return. To use the textbook homily, it affects how the pie is divided, but it does not affect the size of the pie.

Stiglitz and Weiss (1988) have shown that not only is the social return to this kind of information gathering - getting information slightly earlier than other investors--less than the private return, but this is even true of many of the financial innovations (like more rapid recording of transactions) that have occurred in the past decade. More precisely, they show that such financial innovations - to the extent that there are any costs associated with them-actually lead the economy to a Pareto inferior equilibrium. Barring these innovations (were this possible) could actually make everyone better off. The intuition behind this result is simple. Imagine a pile of $\$ 100$ bills lying on the floor, one near each individual. Assume, given the natural lethargy of most individuals, that they all wait two periods to pick up the $\$ 100$ bill. Now consider what happens if one individual wakes up one morning and says to himself, "All the other people are so slow to pick up their $\$ 100$ bill. While they are getting themselves organized, I can pick up the $\$ 100$ bills next to their feet. The extra $\$ 100$ bill(s) will surely be worth the extra effort I have to put out." But, of course, if he does this, all will respond. In the new equilibrium, all the people rush to pick up the $\$ 100$ bill near their feet as quickly as they can. In the end, they have exactly the same amount of money as they did before; but now, they have had to exert energy to rush to pick it up. They are unambiguously worse off.

The large deviation between social and private returns means that there are excessive expenditures on gathering information and on financial innovation. Individuals invest to the point where their marginal private return equals the return they could obtain elsewhere, and since their private return is more than the social return, this means that the net marginal social return is negative.

A turnover tax represents a tax on this kind of activity, and thus will serve to promote economic efficiency by discouraging the excessive expenditures on this form of "rent seeking." It can thus be viewed as a special and potentially important case of a Pigovian corrective tax, a tax that improves economic efficiency at the same time that it raises revenues. 
We now need to ask, are there other serious consequences of such a tax that would impair the ability of the stock market to perform the vital roles that it plays in capitalist economies?

There are three functions commonly ascribed to the stock market, what I shall call (for short) the exchange, the information, and the capital-raising functions. I shall now argue that the most important of these functions may actually be enhanced by a turnover tax, and that none of its important functions are likely to be impaired.

\subsection{Exchange}

The stock market allows individuals to trade with each other. Traditional texts in economics begin with a discussion of the importance of exchange in economics, with the gains to trade. Just as tariffs impede the exchange of goods among countries, turnover taxes impede the exchange of assets among individuals. One of the three fundamental conditions required for the (Pareto) efficiency of the economy is exchange efficiency (all individuals should have the same marginal rate of substitution); the turnover tax interferes with exchange efficiency.

There are, however, two reasons not to be concerned much about this alleged inefficiency. First, the proposed tax rates are sufficiently small that the deadweight loss from the tax (were this a standard problem in economics) is indeed negligible: the deadweight loss is proportional to the square of the tax rate, and hence a tax at the rate of .005 or .01 has a very small deadweight loss. ${ }^{5}$

Second, there are real difficulties in interpreting the welfare losses associated with impeding trades based on incorrect expectations. The standard analysis of exchange takes individuals' preferences as given, and does not ask, for instance, why one individual likes oranges and another likes apples. This is as it should be. But individuals do not demand shares in GM or Ford because they have an intrinsic taste for GM shares or Ford shares. Everyone likes dollars. Each wants more dollars. The demand for GM or Ford shares is based on individuals' expectations concerning the returns that these shares will yield. Exchanges are (largely) motivated by differences in judgments concerning what those yields will be. Thus, to evaluate the consequences of the impediments to trade imposed by a turnover tax, we have to take a closer look at who trades.

1.1.1. A Taxonomy of Traders. We can divide those who trade in these markets into several different categories. A turnover tax will affect these groups differently.

At one extreme, there is a group of individuals who are basically uninformed. The most sophisticated of these have been persuaded by the random walk (dartboard) theory of securities markets, which holds that an individual can do as well throwing darts at a dartboard as by turning his funds over to a specialist in portfolio allocation; and a fortiori, he is not likely to do better than the market spending a few hours a week gathering information from second-hand sources. These individuals buy indexed mutual funds. They do not try to beat the market; they are content to know that they will do no worse than the market.

At the other extreme are highly informed individuals. They could be insiders, for instance, who know that their oil company has struck it rich and that that information has not yet 
leaked out. Or it could be the manager of a research division of a drug company who has just seen a report verifying that the company's best-selling drug causes birth defects. We call these the informed traders.

There is a third group of individuals, called noise traders, who may believe that they understand how the stock market works, who may have theories about the connection between sunspots and stock prices, or between some other observable and stock market prices. These are the dentists and doctors in the Midwest and the retired individuals in the Sunbelt, for whom "following" their favorite stocks is a favorite pastime. We should probably include many of the stock market brokers who advise them (and many of the portfolio managers who manage unindexed funds) within this category.

In between are several groups of individuals who, for simplicity, I shall call partially informed. They include those who study the noise traders ${ }^{\circ}$ and base their trading strategy on "leaning against the wind." They try to take out of the market the noise that the noise traders add. They also include those who try to figure out the "true market value"- the fundamentals-and make purchases and sales when there are big deviations from their calculated values. The trouble with this strategy is that even if an outsider could gather the data on the basis of which he or she could make a reliable calculation of true market value, he or she might have to wait a long time to realize a return; in the short run-which may be years-the deviations between the market price and the "true value" that he or she has calculated may increase, not decrease, and the individual may be forced to sell out at a loss before his or her greater wisdom has been recognized by the market.

It is hard to know whether the stock market was overvalued on October 1, 1987, or undervalued on October 30; but there is a consensus that no event happened during the month that wiped out a quarter of the fundamental value of American corporations. Whatever position one takes, the overvaluation or undervaluation was a persistent one, one that lasted not for minutes or hours, or even weeks, but months, and perhaps years. ${ }^{7.8}$

1.1.2. How the turnover tax would affect different groups. Now we look at how a transfer tax would affect these various groups. The first group-the uninformed-and the truly informed are hardly likely to be affected by a tax at the moderate rates being discussed-less than 1 percent. The uninformed buy securities in diversified portfolios, holding onto them as a form of savings for extended periods of time. If bonds and stocks are treated symmetrically, such a tax would have little effect on either total savings or its allocation. By the same token, the kinds of events that form the basis of insider trading are of sufficient moment that a 1 percent tax is not likely to discourage the trading. Similarly, those who based their trading on fundamentals - who buy stocks when prices differ from fundamentals and are willing to wait for the long term to realize their returns-are also unlikely to have their behavior greatly affected. The 1 percent represents a small fraction of the returns that they must expect before they undertake the risks associated with such an investment strategy.

The turnover tax primarily affects short-term speculators, those who buy and sell within the trading day, and within days or weeks. For these, such a tax may represent a significant fraction of the returns they hope to achieve on each transaction. These short-term traders 
consist of two groups: noise traders and those who live off them.

Those who do not simply buy the market (or an index fund) are betting that they can do better than the market, and that the extra return more than compensates them for the extra risk and extra costs (for instance, in information gathering) that such a strategy entails. The kind of trade that a turnover tax would discourage is based on the mistaken belief of (all!) speculators that they could do better than average. Inevitably, some individuals will have to be disappointed: half must have done worse than average. ${ }^{9}$ Impeding trade is (Pareto) inefficient when viewed from the perspective of their ex ante expectations; impeding trade may actually improve welfare when viewed from the perspective of their ex post realizations. The result is similar to that of the father who forces his son to go to school against his will and who later asks him, "Are you better off as a result?" From an ex ante perspective, such coercion must be welfare-reducing. The child's ex ante expected utility is lower than it otherwise would have been, say, if he had spent the day playing. Ex post. the child agrees that he is better off.

As a society, there is a general consensus-reflected in a variety of laws and regulations-that there may be gains, rather than losses, from taxing or prohibiting gambling. Since the short-term speculative activity - the activities that will bear the brunt of the tax-consist largely of noise traders and those trying to smooth out the market, to make money from the noise traders, there may actually be a welfare gain from impeding these exchanges; in any case, there is not likely to be a significant welfare loss.

One objection arises to this analysis: some might deny the existence, or at least importance, of noise traders. The contention is that such traders would lose money and therefore be weeded out by the market. But this conclusion is wrong. It forgets the famous proposition, attributed, I think, to the great G. T. Barnum: a fool is born every moment. For every fool that is weeded out, a new one enters the market. In spite of the overwhelming evidence of the difficulty of beating the market, small investors continue trying to do it.

The attempt itself is based on the basic proposition that there must be fools in the market. For if any individual does better than the market, it must mean that someone else is, as we have said, doing worse. An individual can guarantee himself the market by buying the market. Thus, to try to beat the market, one must undertake a greater risk-a chance of doing worse; and since rationality would dictate that on average the return will be average, there is no return to compensate for this risk. It is only because each individual believes that he or she is smarter than the other speculators-a proposition that cannot be "rationally" held by all-that the market survives at all. ${ }^{10}$

This kind of irrationality is pervasive. Three-fourths of my students believe that they are in the top half of the class. More generally, we are not good statisticians. There is the famous story of the firm that, in the days before modern medical technology made it possible to predict the sex of a child, nonetheless claimed the ability to do so and promised a money-back guarantee. It made a profit: it always predicted male, and had to return its money only half the time. Individuals are always enticed by the stories of those who have done better than the market - not recognizing that for every such story, there is a closet speculator who has done worse. Individuals who do better than the market always claim it was insight; those who do worse say it was bad luck.

Americans love to gamble, and the stock market-while it serves other important social 
functions-is our largest gambling casino. It is such a popular gambling casino precisely because the winners can tell stories of their insights and theories-theories which, when subjected to the test of scientific verification (can they be used in a predictive manner?) - inevitably fail. Of course, gamblers in Las Vegas and Atlantic City tell stories of their "feel for the dice," their intuition for how things were going to turn out; but somehow, those stories connecting winning with the individual's own merits have a more hollow ring than the claims put forward by the successful stock speculator.

\subsection{Information}

One of the alleged roles of the stock market is that the prices established on the stock market are used to signal the expected returns to different kinds of investments. The stock market provides a mechanism by which information is aggregated - the diverse information of the many different individuals in society is all brought to bear in determining the market value-and transferred, from the informed to the uninformed individuals (Grossman and Stiglitz, 1976, 1980).

The stock market does this aggregation and transferring of information far more quickly and effectively than could be done by alternative methods. Could one imagine the deliberations of a committee assigned the task of determining the value of a stock on the basis of the information each has available?"

Tobin and others have developed theories in which these prices play a central role in the allocation of investment. When stock prices are high, firms know to invest more. While empirical work has provided, at best, weak support to this hypothesis, more recent work (Greenwald and Stiglitz 1988a) has cast doubt about the interpretation of what empirical support has been found and has argued that prices in the stock market play no basic informational role in the economy.

The fundamental question can be put simply: does one really believe that the managers of GM or Ford base their decisions about whether or how to invest on the prices that they see on the stock market? Do they think that those prices-reflecting judgments of the dentists in Peoria and the retired insurance salesmen in Florida-have much, if anything, to add to the analysis of their own market research departments and the reports from their engineers concerning costs of various projects? Any manager who argued that because the price of his stock was high it was therefore a good idea to invest more would, I suspect, quickly find himself looking for another job.

Moreover, the information revealed by the stock market price is not precise enough to be of much use to most firms. It does the firm little good to know that there is some investment project that the market thinks of value. Most investment does not consist of a firm simply expanding its scale of production. The firm must make myriad decisions concerning which of a multitude of possible projects to undertake. Each of these projects has to be evaluated separately. The stock market price simply plays no major role in this process of project evaluation.

In addition, much of the efforts of those gathering information are directed at obtaining 
information that cannot plausibly be of much relevance to firms in their investment decisions, even if it were perfectly reflected in stock market prices. As Summers and Summers (1989) put it,

It is hard to believe ... that investments made with a horizon of hours reveal much socially beneficial information to the market place (p. 16).

One circumstance does exist in which the stock market price will affect the level of investment-when the firm actually decides to raise additional funds from the stock market. But relatively, little investment is financed that way. In the next subsection, we shall argue that a transfer tax may actually enhance the efficiency with which funds raised on the stock market are allocated.

Thus, while it may' be true that prices reflect information (even all information) of the participants in the market, that fact in itself does not mean that that information plays an important role in how investment decisions get made and resources get allocated.

Let me be quite clear about what I am arguing: I am not contending that the stock market price is irrelevant. Firms worry about how their actions affect the stock market price. (Managers who own stock market options may be particularly concerned about this. ${ }^{12}$ ) But managers do not glean information about what machines to buy or where to build a new plant-the information they need for making intelligent investment decisions-from looking at market prices. ${ }^{13}$ The fact that stock market prices and investment decisions may be correlated may simply reflect the fact that managers and the market are responding to some of the same signals concerning the firm's prospects.

\subsection{Raising capital}

The third function that the security markets perform I have just alluded to: they help firms raise new capital. There is an important link between this third function and the first, the exchange function. Individuals are willing to buy shares in a firm because they are marketable, because the individual can sell them, at relatively low cost, should it turn out that he or she needs the cash for any purpose. Interfering with the exchange function thus might interfere with the ability of the market to perform its capital-raising function.

Of the three functions, it is only this last function to which I attach some limited importance. I do not think it would be greatly impeded by a small transfer tax; to some extent, I think it would be enhanced, for reasons I will explain below.

In the next section, I will argue that a tax on turnover may reduce stock market volatility. I see a distinct advantage arising from a reduction in volatility. For, to the extent that volatility would be reduced, the buyer of the security bears less risk concerning the price he or she will receive when he or she sells it. Thus, reducing the volatility will make it easier for firms to raise equity capital. ${ }^{14}$

Reducing volatility will also increase the efficiency with which capital is allocated. The one time that firms find it attractive to issue new shares is when the market has overvalued their shares. In that case, firms do more investment than is "socially" desirable, simply because they are obtaining funds at a lower rate, because of the unreasonable expectations 
of noise traders. This is one of the reasons why high volatility is undesirable: it makes this kind of misallocation of investment more likely.

If one thinks, as I do, that the most important function (from the social view) of the stock market is raising new equity, one cannot but be struck by how, under current circumstances, it seems to do so little of this at such great cost. As I noted earlier, only a small fraction of investment is financed by new issues on the stock market. In spite of the huge improvements in efficiency in the financial sector, the costs of running the financial sector are huge. Summers and Summers note that these costs, which can be viewed as part of the transactions costs of running the capitalist economy, amounted in 1987 to 16 percent of the profits of the corporate sector; a more inclusive measure of the costs brings them up to a quarter of corporate income and half of corporate net investment-and a multiple of the value of new funds raised in the stock market. Of course, most of these resources are not spent in raising new funds but in rearranging ownership claims on society's resources. They are a part of the quest for rents. They affect who gets the returns to society's productive assets, not which investments get made. Resources devoted to gambling-and to short-term speculation in the stock market-could be devoted to more productive uses. (I include in these relatively unproductive use of resources not only the transactions costs but also much of the costs spent on acquiring information, including the extra costs of getting the information slightly earlier than it would otherwise become available.) As an educator, I must convey to you my sense of disappointment as some of my best students decide to devote their lives to the quest for rents rather than to trying to increase society's productive potential. Though I am not confident that a turnover tax of $1 / 2$ or 1 percent is likely to have a significant effect in this direction, it will help at the margin.

There is another argument sometimes put forth as to why a turnover tax may enhance the efficiency of the economy. A turnover tax is largely a tax on short-term speculation. As a percentage of long-run returns, a 1 percent turnover tax becomes negligible. If an investor is contemplating making an investment for 20 years, with a 7 percent return per year, a 1 percent turnover tax will reduce his or her return over the interim by only $1 / 2$ percent. If the proportion of investors in the market that are long term is increased, then presumably the attention of firms will be directed toward the long term. There has been a concern that the focus on short-term returns has forced managers to focus on short-term profits, possibly to the detriment of long-run profitability. ${ }^{15}$ Thus, this reorientation of managerial focus may provide another reason why a turnover tax may have some beneficial effects.

While I have focused my attention in this section on the stock market, similar arguments apply to bond markets, with perhaps even greater force. For the main determinant of future bonds prices are future interest rates. The task of speculators is thus to forecast the policy of the Federal Reserve Board. Here, I must confess a professional weakness: I simply do not believe that the dentist in Peoria-or his stock broker—can do a better job of predicting those policy changes than the major econometric models. I cannot but believe that whatever he bases his guesses on, they can only be thought of as adding noise to the market. And if it were desirable that information about future Federal Reserve policies be made public. then wouldn't it make more sense for the Fed to announce that information, rather than having others try to second-guess the Fed? 


\section{Price determination and price volatility}

Prices on the stock market-as in other competitive markets-are determined by the intersection of demand and supply. But the demand and supply of assets, such as stocks, differ from that for commodities like wheat because their principal determinant is individuals' expectations about what those assets can be sold for at some date in the future. They are based, in other words, on expectations, and these expectations can obviously change dramatically in short periods of time. That is why prices on stock markets can be so volatile.

Some critics of turnover taxes have expressed a concern that such taxes would result in thinner markets, leading to greater volatility and less liquidity. In this section, I explain why I am not persuaded by those objections, and indeed, it seems quite plausible that such a tax may actually reduce price volatility.

The analysis of this section is divided into three parts. First, I explain why while a turnover tax is likely to lead to thinner markets, it is not likely to lead to significantly larger spreads between buying and selling prices. It may actually lead to smaller spreads. Second, I argue that among those who find it no longer profitable to trade are a disproportionate number of individuals who contribute to market volatility; as a result, the thinner markets, instead of leading to increased price volatility, may well result in reduced volatility.

\subsection{A turnover tax leads to thinner markets but not necessarily larger spreads}

A tax on turnover is likely to discourage some individuals who otherwise have traded in the market from doing so. It will discourage sellers as well as buyers. If its effects were symmetric, it would simply make the market thinner.

Thinner markets have a bigger spread between buying and selling prices, and in that sense are less liquid. The usual argument for this is simple: buyers and sellers do not in general arrive in the market at the same time. With thinner markets, it may take a longer time for, say, a seller to be matched up with a buyer. Market makers make the market by buying from the seller, then holding the security in inventory until the buyer arrives. The market makers need to be compensated for performing this function (both for the capital which is tied up and the risks which are borne). Such a transfer tax thus has not only a direct effect in increasing the spread between buying and selling price but an indirect effect as well. For widely traded stocks, on both theoretical and empirical grounds, it is hard to believe that this effect would be significant. The extra "carrying" time is probably minutes, perhaps even seconds, and it is hard to see-if markets work reasonably well-how this effect could be significant.

\subsection{Why a turnover tax may reduce volatility}

In the previous section, we placed investors into four different categories, and argued that a turnover tax would serve to discourage primarily noise traders and those who live off them. 
Since these traders add to the noise of the market, discouraging them will lead to less volatile markets.

One objection to this argument is that, while it may discourage noise traders (who, as their cumulative after tax losses will appear larger, will drop out of the market more rapidly, and who, aware of the tax, will engage in trades only when they are confident of larger returns), it also discourages those who live off the noise traders, the arbitrageurs who stabilize the market in the short term. Isn't it possible that these individuals are discouraged even more than the noise traders? And, in that case, couldn't the market be even more volatile? There is such a possibility, but theoretical arguments and empirical evidence suggest that we should not give too much weight to that possibility.

Assume, on the one hand, that these arbitrageurs were doing a good job, and that as a result, in spite of the noise traders, prices were following their "true" values. Now, there is a tax, which makes it unattractive for them to buy or sell the stock unless the price deviates more than 1 percent from its true value. Then it is possible that there may be more volatility - within this 1 percent window of true value-but relative to the magnitude of volatility that we observe, this would seem to be truly a second order effect. It is also possible that the market would be less volatile, since prices will not adjust to reflect small changes in true values.

We can establish two general propositions. First, if an individual decides to switch from one security into another, the transfer tax will not affect the timing of the switch. ${ }^{16}$ Second, the deviations from true market value cannot be greater on average than the magnitude of the tax. Since the size of the proposed taxes is small, the maximum increase in volatility is negligible. The argument establishing the upper bound on the increase in volatility makes it clear that the normal expectation is that there will be a significant reduction in volatility, as noise traders drop out of the market. ${ }^{17}$

The empirical evidence supports the hypothesis that such a tax would not likely increase volatility and might well reduce it. The effect of transactions costs are similar to those of a turnover tax. They represent a wedge between the buying and selling price. The past two decades have seen marked changes in transactions costs. While many other changes have also occurred, there is little evidence to suggest that markets are less volatile now than they were two decades ago. Recent experience provides strong suggestions to the contrary.

Closing a market can be viewed as an extreme case of a prohibitive tax. Does closing the market for a day lead to more or less variability in stock prices? If the market was basically tracking changes in fundamentals, the difference between the opening price on Thursday morning and the closing price on Tuesday night should be unaffected by the closing the market on a Wednesday. If much of the volatility in the market is contributed by noise traders, then closing the market on Wednesday will have reduced their opportunities to add noise to the market (some of which, admittedly. will have been removed by the arbitrageurs making money off them, but they will not have fully done their job). In this view, then, the deviation of the market price on Thursday morning from the close on Tuesday will be smaller if the market is closed on Wednesday. French and Roll (1987) provide convincing evidence that during the period in 1968 when the market was closed on Wednesday (because of the inability of the back rooms to keep up with the increasing volume of trade), volatility was greatly reduced—by a factor of $1 / 2 !^{18}$ 
Indeed, there are other theoretical arguments to suggest that short-term trading contributes little to price stability. The objective in short-term trading is to obtain information before others do. Information obtained more quickly is likely to be noisier. Assume, for instance, that there is a weekly shift in a fundamental variable describing a security. The value of this fundamental variable becomes publicly available at 2:00 pm on Friday. Individuals speculate all week long about what that value is. As Friday approaches, their information becomes better. The rush to get information about the value on Friday will result in statistics on Monday that are quite noisy estimators of Friday's value; but, of course, Monday's price will (in a well-functioning market) fully reflect that information.

If firms had to take actions on Tuesday morning and had to rely on the stock market value for taking those actions, then there would be some value in having this "early" information, as noisy as it is. But I argued in the previous section that early information is of little or any productive value. Indeed, to the extent that it contributes to price volatility, it will have negative effects on the economy, as I suggested above.

\section{Implementing a turnover tax}

A turnover tax has some distinct advantages relative to other capital taxes, particularly to capital gains taxes. The capital gains tax distorts individuals' holding periods, while the fundamental result established in section 2 is that, for those who still find it profitable to trade, the turnover tax will lead them to trade at the same time that they otherwise would have traded.

Moreover, the turnover tax has the property of (on average) automatically phasing itself out for long-term investments; that is, as a proportion of returns, it becomes negligible as the holding period increases. Thus, it will not have a significant affect on long-term investors. Its major impact will be on short-term noise traders and those who live off them.

The turnover tax has two other advantages over a capital gains tax. First, it avoids the arbitrage opportunities inherent in a capital gains tax that allows even limited loss deductability (see Stiglitz, 1983). Second, since a tax with loss deductability subsidizes losers while taxing winners, it effectively subsidizes noise traders (who, it will be recalled, on average lose money). and it taxes arbitrageurs. This differential effect may accordingly lead to increased price volatility.

There is one difficult problem in implementing such a tax, which is how to treat equitably and efficiently different categories of assets. A turnover tax on the stock market would simply encourage speculation to move to the options market. A turnover tax on the options market, based on the value of the option, would have a similar effect. Buying a call option and selling a put is equivalent to buying the share; thus, to avoid distortions, this combined transaction must face the same tax. Accordingly, to avoid a distortion, the tax imposed on the options market must be based on the striking price. (A tax at half the rate imposed on the stock, imposed on each, the call option and the put, would be roughly neutral.) But the tax would then be a large proportion of the value of the transaction. Since I am not sure that much harm-and some good - could result from discouraging the kind of short-term speculation that predominates in these markets, this does not bother me too much. but $\mathrm{I}$ suspect that it would generate considerable opposition. 
Let me mention briefly one other concern. The tax reduces the return on savings and, critics charge, this will reduce savings. There is little evidence of a large elasticity of supply of savings, and hence one would not have thought that a 1 percent tax would have a significant effect on funds put away for 10 or 20 years. If, however, one decided that this was a concern. one could easily allow for a phasing down of the tax rate for investments held over several years.

\section{Concluding remarks}

No institution in our capitalist society is as venerable as the stock market. A turnover tax might seem, at first glance, to be an attack on this foundation of our economy. I have tried to argue that such a tax is likely to increase the overall efficiency of the economy and may actually enhance the efficiency with which the stock market performs its most important roles. The fact that at the same time it raises revenues-reducing the size of the national deficit - is but one additional benefit of a tax which, on its own merits, seems desirable.

\section{Notes}

1. Other taxes, such as capital gains tax, would have quite similar effects. I argue below (section III) that a turnover tax has some distinct advantages over a capital gains tax. For most of the analysis, I shall consider a flat rate tax, with the rate of taxation not depending on the holding period. The consequences of alternative provisions are discussed briefly in section III.

2. It used to be thought that because such taxes introduce additional distortions, they were therefore inefficient. Since Ramsey's classic 1927 article, it has been recognized that such an argument is false: one cannot simply count the number of distortions. Two little distortions could, in principle, be preferable to one large distortion. Atkinson and Stiglitz (1976) have shown, however, that in at least one central case, the general presumption against selective commodity taxes remains valid. For a more general exposition, see Atkinson and Stiglitz (1980).

3. An economy is Pareto efficient if no one can be made better off without making someone else worse off. The term constrained Pareto efficiency is employed simply to remind us that in evaluating whether a government policy would constitute a Pareto improvement, we need to take into account the constraints facing the private sector in particular, the fact that information is imperfect and costly to obtain.

4. This version of the argument was set forth-considerably earlier than the general theorem-by Hirschleifer (1971) and Stiglitz (1971).

5. One might argue that a turnover tax of even .5 percent represents a substantial fraction of the expected return for a short-term investment. But this is an inappropriate way to view the distortion. The question is, how different can the marginal rates of substitution between two assets between two individuals be without trade occurring? If their relative valuations of two assets differed by more than 1 percent, it would pay them to trade.

6. These are the judges in Keynes' famous beauty contest, whose objective was not to decide who was the most beautiful contestant but who the other judges were likely to think was the most beautiful.

7. There is, in theory, the possibility of a fifth group, those who turn to the stock market to hedge against certain risks that they face. In the futures market, these hedgers are an important class of participants, but they do not appear to be important in the stock market. Workers in the automobile industry do not sell short automobile stocks to hedge against the risks of being unemployed; on the contrary, their pension funds tend to be disproportionately weighted toward risks that are correlated with their employment risks. (In some cases, there may be good institutional reasons, such as preferential tax treatment, for these portfolio decisions.) In any case, however, the market provides little information concerning the correlation of specific securities with particular categories of risk; the only 
correlation that is conventionally provided is with the market as a whole. This suggests that few investors find such information of value in making their portfolio decisions.

$\delta$. It is worth noting that even the return of the fully informed depends on the existence of the noise traders; if all individuals were of the first type, and simply purchased the market, the truly informed would affect market prices but would not be able to reap returns.

9. This would only be correct if the distribution of gains and losses were symmetric. More realistically, the stock market is like a lottery: many individuals lose a little, and a few gain a lot. If this is true, then more than half of the individuals are disappointed.

10. This proposition was originally asserted in Stiglitz (1971), and more formally stated and proved in Stiglitz (1982a). More formal proofs are provided by Milgrom and Stokey and by Tirole.

11. While we showed precisely how markets perform their role of aggregating and transferring information, we also showed that as long as information was costly, capital markets would never be efficient, that is, not all the information would be conveyed from the informed to the uninformed. Gale and Stiglitz (1985) and Jordon also show that it is only under highly special conditions that markets perfectly aggregate information, that is, that one can infer from the market price, say, all the relevant information of the participants in the market.

12. Indeed, the fact that they are particularly concerned about the short-run movements in the stock market has long been a criticism of managerial compensation schemes that relate pay to performance in the near term, rather than in the more distant future.

13. Moreover, given the kinds of criteria conventionally employed in undertaking an investment project, a small revision in market value would virtually never affect whether a project was undertaken. Given that, what value can there be to having information that would revise that value one minute earlier?

14. Greenwald and Stiglitz (1987a, 1987b, 1988) have argued, in turn, that making it easier to raise equity will have important benefits in ameliorating business cycles; they attribute much of the cyclical fluctuations to the inability of firms to divest themselves of the risks they face.

15. Dramatic evidence of this is provided by firms that failed to take advantage of accelerated depreciation, LIFO accounting, and other tax provisions that reduced reported income while reducing the present discounted value of tax payments.

16. The argument is simple. Assume the expected instantaneous return on security $i$ at time $t$ is $r_{i}(t)$, and let

$$
R_{i}(1, T)=T r_{i}(\tau) d \tau
$$

Then the total return from holding security 1 from 0 to $t$, and security 2 from $t$ to $T$ is

$$
(1-\gamma)^{2} \exp R_{1}(0, t) \exp R_{2}(t, T)
$$

where $\gamma$ is the turnover tax rate. The value of $t$ at which this is maximized is independent of $\gamma$.

17. Consider a 1 percent tax. If, in an average period, the maximum deviation was more than 1 percent greater than it had previously been, any arbitrageur who previously found it profitable to speculate would still find it profitable to do so. Hence, the supply of arbitrage services would remain unchanged. Yet the need for arbitrage services is reduced, since the return to noise traders after tax is lower (more negative.)

18. There is a vast recent literature providing empirical support to the argument that stock prices do not track fundamental values well, and that there is the kind of noise in prices consistent with a theory that ascribes importance to noise traders. See, for instance, Shiller (1981).

\section{References}

Atkinson, A.B. and Stiglitz, J.E. "The Design of Tax Systems." Journal of Public Economics, 1976. Lectures in Public Economics. New York: McGraw Hill, 1980.

Black, Fischer. "Noise." Journal of Finance (1986), 529-543.

DeLong, J. Bradford, Shleifer, Andrei, Summers, Lawrence H., and Robert J. Waldmann." Noise Trader Risk in Financial Markets." Mimeo, October 1988. 
"The Size and Incidence of the Losses from Noise Trading." NBER Discussion Paper, March 1989.

Edwards, Franklin R. "Policics to Curb Stock Market Volatility." Center for the Study of Futures Markets, Columbia University, Working Paper 176, August 1988.

French. Kenneth and Roll, Richard. "Stock Return Variances: The Arrival of Information and the Reaction of Traders." Journal of Financial Economics (1987), 5-26.

Gale, I. and Stiglitz, J.E. "Futures Markets Are Almost Always Informationally Inefficient." Princeton University Financial Research Center Memorandum No. 57, February 1985.

Greenwald, B. and Stiglitz, J.E. "Externalities in Economies with Imperfect Information and Incomplete Markets." Quarterly Journal of Economics (May 1986), 229-264.

Greenwald, B. and Stiglitz, J.E. "Imperfect Information, Credit Markets and Unemployment." European Economic Review 31 (1987a), $444-456$.

$119-133$

"Keynesian, New Keynesian and New Classical Economics." Oxford Economic Papers 39 (1987b),

. . "Examining Alternative Macroeconomic Theories," Brookings Papers on Economic Activity No. 1, $207-270$.

. "Information, Finance Constraints and Business Fluctuations." In: Meir Kohn and S.C. Tsiang, eds., Finance Constraints, Expectations and Macroeconomics. Oxford: Oxford University Press, 1988b, pp. 103-141. Grossman, S. and Stiglitz, J.E. "Information and Competitive Price Systems." American Economic Revie'u 66 (May 1976), 246-253.

1980), 393-408.

Hirschliefer, J. "The Private and Social Value of Information and the Reward to Incentive Activity." American Economic Review' (September 1971), 561-574.

Jensen, Michael C. "Symposium on Some Anomalous Evidence Regarding Market Efficiency." Journal of Financial Economics 6 (June/September 1978). 95-101.

Jordan, J.S. "On the Efficient Markets Hypothesis." Econometrica 51(1983), 1325-1343.

Keynes, J.M. The General Theory of Employment, Interest, and Money. London: Macmillan, 1936.

Milgrom, Paul and Stokey, Nancy. "Information, Trade, and Common Knowledge." Journal of Economic Theory26 (1982), 17-27.

Ramsey, F.P. "A Contribution to the theory of Taxation." Economic Journal (1927), 47-61.

Roll, R., [paper presented at this conference]

Shiller, Robert J. "Do Stock Prices Move Too Much To Be Justified by Subsequent Changes in Dividends?" AER71 (June 1981), 421-436.

Stiglitz, J.E. "Perfect and Imperfect Capital Markets." Paper presented to Econometric Society Meetings, New Orleans, December 1971.

. "Information and Capital Markets." In: William F. Sharpe and Cathryn Cootner, eds., Financial

Economics: Essays in Honor of Paul Cootner. Englewood Cliffs. NJ: Prentice Hall, 1982a, pp. 118-158.

257-294.

Stiglitz, J.E. and Weiss, A. "Banks as Social Accountants and Screening Devices for the Allocation of Credit." NBER working paper no. 2710, September 1988.

Economics of the Public Sector. New York: W.W. Norton Publishers, 1986; 2 d ed., 1988.

Summers, L.H. and Summers, V.P. "When Financial Markets Work Too Well: A Cautious Case for a Securities Transactions Tax." Paper presented to the Annenberg Conference on Technology and Financial Markets, Washington, D.C., February 28, 1989.

Tirole, J. "On the Possibility of Speculation Under Rational Expectations." Econometrica 50 (September 1982). $1163-1181$. 
Copyright of Journal of Financial Services Research is the property of Springer Science \& Business Media B.V.. The copyright in an individual article may be maintained by the author in certain cases. Content may not be copied or emailed to multiple sites or posted to a listserv without the copyright holder's express written permission. However, users may print, download, or email articles for individual use. 